\title{
UPAYA MENINGKATKAN HASIL BELAJAR PJOK MATERI TENIS MEJA MELALUI MEDIA DINDING PADA SISWA KELAS VII.4 SMPN 3 SELAT TAHUN PELAJARAN 2019/2020
}

\author{
Mardiyanto \\ SMPN 3 Selat, Kapuas, Kalimantan Tengah \\ Email: mardiyanto@smpn3selat.sch.id
}

\begin{abstract}
Abstrak: $\quad$ Latar belakang penelitian ini adalah masih banyak siswa yang belum mampu melakukan teknik dasar bermain tenis meja, selain itu banyak dari siswa yang belum tuntas mencapai Kriteria Ketuntasan Minimum (KKM) dengan nilai 70. Rumusan masalah berdasarkan latar belakang adalah sebagai berikut: Apakah penerapan media dinding dapat meningkatkan hasil pembelajaran tenis meja pada siswa kelas VII.4 SMPN 3 Selat. Tujuan dari penelitian ini adalah untuk mengetahui: peningkatan hasil belajar tenis meja siswa kelas VII.4 SMPN 3 Selat melalui penerapan modifikasi alat pembelajaran. Penelitian ini adalah penelitian tindakan kelas yang dilaksanakan dalam dua siklus. Setiap siklus mempunyai 4 langkah yaitu: perencanaan, pelaksanaan, observasi, dan refleksi. Sumber data penelitian ini adalah siswa Kelas VII.4 SMPN 3 Selat yang berjumlah 30 orang yang terdiri dari 13 siswa laki-laki dan 17 siswa perempuan. Teknik pengumpulan data dengan observasi, tes kemampuan dan hasil belajar bermain tenis meja. Teknik pengumpulan data dengan observasi, tes kemampuan dan hasil belajar bermain tenis meja. Teknik analisis data yang digunakan dalam penelitian ini adalah secara statistic deskriptif kualitatif. Berdasarkan hasil penelitian bahwa pembelajaran melalui penerapan modifikasi alat pembelajaran dapat meningkatkan hasil belajar tenis meja pada siswa kelas VII.4 SMPN 3 Selat. Dari hasil analisis yang diperoleh terjadi peningkatan yang sangat signifikan dari siklus I dan siklus II. Hasil belajar pada siklus I dalam kategori tuntas adalah 41,94\% dan pada siklus II terjadi peningkatan hasil belajar siswa dalam kategori tuntas sebesar 87,10\%. Maka dapat disimpulkan bahwa pembelajaran tenis meja melalui media dinding dapat meningkatkan hasil belajar siswa SMPN 3 Selat. Dari hasil analisis yang diperoleh peningkatan yang signifikan dari siklus I dan siklus II. Beberapa saran, khususnya pada guru SMPN 3 Selat sebagai berikut: guru hendaknya lebih inovatif dalam menyampaikan materi pembelajaran. Guru hendaknya memberikan pembelajaran kepada siswa dengan permainan sederhana tetapi mengandung unsur materi, agar siswa tidak jenuh dalam mengikuti pembelajaran. Guru hendaknya memberikan modifikasi alat pembelajaran yang sederhana, efisien, efektif, dan tidak memerlukan biaya mahal untuk membuatnya yang dapat dilihat atau dipegang langsung oleh siswa, karena dapat memotvasi sisw untu selalu mencoba dan mengulangi terus-menerus.
\end{abstract}

Kata Kunci: hasil belajar, tenis meja, media dinding 
Abstract: The background of this research is that there are still many students who have not been able to do the basic techniques of playing table tennis, besides that many students have not yet completed the Minimum Completion Criteria (KKM) with a score of 70.The formulation of the problem based on the background is as follows: Is the application of wall media can improve the results of learning table tennis in class VII.4 SMPN 3 Selat. The purpose of this study was to determine: the improvement of learning outcomes in table tennis for VII.4 grade students of SMPN 3 Selat through the application of modified learning tools. This research is a classroom action research conducted in two cycles. Each cycle has 4 steps, namely: planning, implementing, observing, and reflecting. The data source of this research was students of Class VII.4 SMPN 3 Selat, totaling 30 people consisting of 13 male students and 17 female students. Data collection techniques using observation, ability tests and learning outcomes to play table tennis. Data collection techniques using observation, ability tests and learning outcomes to play table tennis. The data analysis technique used in this research is qualitative descriptive statistics. Based on the results of the study, learning through the application of modified learning tools can improve learning outcomes of table tennis in class VII.4 students of SMPN 3 Selat. From the results of the analysis obtained a very significant increase from cycle I and cycle II. The learning outcomes in the first cycle in the complete category were $41.94 \%$ and in the second cycle there was an increase in student learning outcomes in the complete category by 87.10\%. So it can be concluded that learning table tennis through wall media can improve student learning outcomes at SMPN 3 Selat. From the analysis results obtained a significant increase from cycle I and cycle II. Some suggestions, especially for SMPN 3 Selat teachers are as follows: teachers should be more innovative in delivering learning material. Teachers should provide learning to students with simple games but contain material elements, so that students are not bored in following the lesson. The teacher should provide a simple, efficient, effective, and cost-effective modification of learning tools to make it visible or held directly by students, because it can motivate students to always try and repeat it continuously.

Keywords: learning outcomes; table tenis; wall media.

\section{PENDAHULUAN}

Pendidikan merupakan sarana yang tepat dalam mengembangkan potensi yang dimiliki manusia, karena dengan pendidikan dapat dibentuk manusia yang berpengetahuan, berkepribadian dan memiliki keterampilan sehingga pada nantinya terwujud keseimbangan antara aspek jasmani dan rohani dalam upaya mencapai perkembangan yang lebih maju dari sebelumnya

Pendidikan nasional berfungsi menembangkan kemampuan dan membentuk watak serta peradaban bangsa yang bermartabat dalam rangka mencerdaskan kehidupan bangsa bertujauan untuk berkembangnya potensi peserta didik agar menjadi manusia yang beiman dan bertakw kepada Tuhan Yang Maha Esa, berakhlak mulia, sehat, berilmu, cakap, kreatif, mandiri dan menjadi warga negara yang demokratis serta bertanggung jawab (Sinar Grafika, 2007). 
Undang- undang RI Nomor 3 Pasal 1 Tahun 2005 menyatakan bahwa Olahraga Pendidikan adalah jasmani dan olahraga yang dilaksanakan sebagai bagian proses pendidikan yang teratur dan berkelanjutan untuk memperoleh pengetahuan, kepribadian, keterampilan, kesehatan dan kebugaran jasmani. Pendidikan jasmani, olahraga dan kesehatan merupakan program pengajaran yang sangat penting dalam pembentukan kebugaran para siswa. Pembelajaran jasmani olahraga dan kesehatan ini diharapkan dapat mengarahkan siswa untuk dapat beraktivitas olahraga agar tercipta generasi muda yang sehat dan kuat. Pendidikan jasmani olahraga dan kesehatan yang diajarkan di sekolah- sekolah memiliki peranan yang sangat penting dalam berbagai hal diantaranya: memberikan kesempatan kepada siswa untuk terlibat langsung dalam berbagai pengalaman belajar melalui aktifitas jasmani, permainan, dan cabang olahraga terpilih yang dilakukan secara sistematis. Pembekalan pengalaman belajar yang diarahkan untuk membina fisik, perkembangan watak, keterampilan gerak, kepribadian yang harmonis dan sekaligus membentuk pola hidup sehat dan bugar sepanjang hayat.

Dalam kurikulum tingkat satuan pendidikan salah satunya menyebutkan bahwa strategi pembelajaran adalah melaksanakan Pembelajaran Aktif, Inovatif, Kreatif, Efektif, dan Menyenangkan (PAIKEM). Strategi pembelajaran PAIKEM merupakan salah satu strategi yang dapat diterapkan dalam pembelajaran, karena bidang garapannya tertuju bagaimana cara: (1) pengorganisasian materi pembelajaran, (2) menyampaikan atau menggunakan metode pembelajaran, dan (3) mengelola pembelajaran (Hamzah dan Mohamad, 2016:60). Untuk mencapai tiga garapan tersebut di atas, seorang guru bisa memodifikasi alat pembelajaran dan dapat dikaitkan dengan kondisi lingkungan pembelajaran.

Guru dapat mengurangi atau menambah kompleksitas dan kesulitan tugas ajar dengan cara memodifikasi peralatan yang digunakan untuk melakukan skill itu, misalkan beratringannya, tinggi- rendahnya, panjang- pendeknya peralatan yang digunakan.

Salah satu standar kompetensi dari mata pelajaran Pendidikan Jasmani, Olahraga, dan Kesehatan di Sekolah Menengah Pertama adalah Mempraktikkan variasi dan kombinasi gerak spesifik dalam berbagai permainan bola kecil sederhana dan atau tradisional. Salah satu diantara permainan bola kecil yang diajarkan adalah tenis meja. Tenis meja adalah suatu permainan yang menggunakan meja sebagai lapangan dibatasi oleh jaring (net) yang menggunakan bola kecil tebuat dari celluloid dan permainannya menggunakan pemukul atau yang disebut bat. Terdapat 4 peralatan yang dibutuhakan untuk bermain tenis meja: meja, net, bola dan bet.

Di dalam permainan tenis meja ada beberapa teknik yang perlu dipelajari yaitu cara memegang bet, memukul, dan cara berdiri. Tidak dapat dipungkiri bahwa dalam proses belajar-mengajar yang bersifat klasikal (hanya menyampaikan teori tanpa langsung dipraktikkan) akan menghadapi permasalahan yang heterogen terhadap kemampuan siswa. Dimana kurangnya kreatifitas seorang guru pendidikan jasmani di dalam mengemas materi pembelajaran pendidikan jasmani dianggap sebagai penyebabnya, sehingga banyak dari siswa yang tidak tuntas nilai Kriteria Ketuntasan Minimal (KKM) dengan nilai 70. Untuk itu dituntut seorang guru pendidikan jasmani yang mampu menguasai berbagai model atau pendekatan pembelajaran praktik, sehingga pembelajaran dapat berlangsung dengan baik dan berkualitas.

Hasil dari pengamatan pengamatan proses pembelajaran tenis meja pada siswa Kelas VII.4 SMPN 3 Selat belum berjalan dengan baik, masih banyak siswa yang belum bisa melakukan teknik dasar permainan tenis meja, dalam proses pembelajaran bermain tenis meja banyak siswa yang belum mempraktikkan teori-teori yang dipergunakan dalam permaianan tenis meja. Dalam proses pembelajaran permainan tenis meja, yang dilakukan guru sebagai penulis selama satu tahun banyak siswa yang belum menguasai teknik 
dasar permainan tenis meja. Alasan yang mendasar faktor tersebut di atas yaitu dari jumlah siswa secara keseluruhan 540 orang, hanya memiliki satu buah lapangan tenis meja.

\section{KAJIAN TEORI}

\subsection{Hasil Belajar}

Belajar merupakan suatu proses kegiatan, sedangkan hasil dari kegiatan belajar itu dikenal sebagai hasil belajar atau prestasi belajar. Seseorang dikatakan berhasil atau tidak dapat dilihat dalam bentuk nilai-nilai yang mencerminkan prestasi atau sejauh mana keberhasilan seseorang dalam mengikuti kegiatan belajar itu.

Seseorang dinyatakan memiliki hasil yang tinggi apabila nilai yang dicapainya tinggi, dinyatakan memiliki keberhasilan sedang apabila nilai-nilai yang dicapainya sedang, dan memiliki kebehasilan rendah bila nilai-nilai yang dicapainya rendah.

Hasil Belajar atau prestasi belajar merupakan hasil dari segala kemampuan yang dicurahkan oleh siswa untuk menguasai ilmu pengetahuan dan ketrampilan yang sesuai dengan kurikulum yang berlaku. Prestasi belajar ditentukan melalui pengukuran dan hasil akhirnya berbentuk rapor yang diberikan guru dalam periode waktu tertentu melalui teknik pemberian ulangan atau ujian baik lisan maupun tertulis. Indikator keberhasilan belajar mengajar menurut Pupuh Fathurrohman (2007: 113) meliputi:

1. Daya serap terhadap bahan pengajaran yang diajarkan mencapai prestasi tinggi, baik secara individu maupun kelompok

2. Perilaku yang digariskan dalam tujuan pengajaran khusus (TPK) telah dicapai oleh siswa baik secara individu maupun kelompok.

3. Terjadinya proses pemahaman materi yang secara sekuensial mengantarkan materi tahap berikutnya.

Kegiatan belajar mengajar dapat dikatakan berhasil apabila prestasi belajar dari siswa itu baik, paling tidak setiap anak mengerti dan paham dengan apa yang diajarkan oleh seorang guru. Tujuan pendidikan berhasil atau tidak dapat dilihat dan diukur dari nilai yang dicapai oleh peserta didik dalam belajarnya.

Hasil belajar dapat diukur dengan menggunakan tes prestasi belajar, untuk mengetahui tinggi rendahnya hasil seseorang dalam belajar, baik berdasar dari kelompok norma yaitu membandingkan hasil belajar seseorang, atau siswa yang satu dengan siswa yang lainnya, ataupun berdasarkan kriteria yang telah ditetapkan sebelumnya. Keberhasilan belajar juga dapat membantu siswa untuk mengembangkan dirinya, yaitu membantu individu-individu mengenal dirinya sendiri mewujudkan potensi-potensi yang ada pada diri mereka sendiri.

\subsection{Tenis Meja}

Tenis meja, atau ping pong, adalah suatu olahraga raket yang dimainkan oleh dua orang (untuk tunggal) atau dua pasangan (untuk ganda) yang berlawanan. Permainan ini menggunakan raket yang terbuat dari papan kayu yang dilapisi karet yang biasa disebut bet, sebuah bola pingpong dan lapangan permainan yang berbentuk meja. Cara beramain menggunakan bet untuk memukul bola memantul ke meja sendiri kemudian melewati net dan memantul ke meja lawan kemudian dipukul secara bergantian. Dalam 1 set diselesaikan setelah pemain memperoleh nilai 11 . Untuk memenangkan permainan seorang pemain harus meraih 3 set kemenangan. Tenis meja dapat dimainkan secara tunggal maupun ganda.

Menurut Simson (1986:5) tenis meja merupakan salah satu cabang olahraga yang banyak penggemarnya, tidak terbatas pada tingkat usia remaja saja, tai juga anak-anak dan orang tua, pria dan wanita cukup bsesar peminatnya, hal ini disebabkan karena olahraga yang satu ini tidak telalu rumit untuk diikuti. 
Menurut Muhajir (2016:94), tenis meja adalah cabang olahraga yang dimainkan di dalam gedung (indoor game), oleh dua atau empat pemain menggunakan bet yang dilapisi karet untuk memukul bola celluloid melewati jaring di atas meja yang dikaitkan pada dua tiang jaring.

\section{METODE PENELITIAN}

Jenis penelitian ini adalah Penelitian Tindakan Kelas (PTK). Penelitian ini merupakan penelitian tindakan kelas (classroom action research) menurut Arikunto, dkk (2014:3) penelitian tindakan kelas merupakan suatu pencermatan terhadap kegiatan belajar berupa sebuah tindakan, yang segaja dimunculkan dan terjadi dalam sebuah kelas secara bersama. Menurut Ekawarna, (2010:4) penelitian tindakan kelas adalah Penelitian tindakan (action reseach) yang dilksnakan oleh guru di dalam kelas. Dalam penelitian ini guru diberdayakan dari sudut pengembangan profesionalitas sedangkan siswa mendapat manfaat dari upaya guru karena mendapat layanan yang lebih baik karena dampak dari meningkatnya kualitas pembelajarannya. Muslich, Mansur (2014:41) Penelitian Tindakan Kelas adalah penelitian yang dilakukan oleh guru di dalam kelasnya sendiri melalui refleksi diri, dengan tujuan untyuk memperbaiki kinerjanya sebagai guru, sehingga proses pendidikan itu dpat berjalan dengan baik, dan hasil belajar siswa meningkat.

Penelitian Tidakan Kelas ini merupakan penelitian yang mengacu kepada tidakan yang dapat dilakukan secara langsung dalam usaha memperbaiki proses pembelajaran. Penelitian ini dipilih karena memiliki karakteristik yang sesuai dengan tujuan penelitian, yakni untuk menigkatkan hasil belajar penjas terutama mengusai teknik smash dalam permainan tenis meja.

Penelitian ini dilaksanakan di SMP Negeri 3 Selat. Waktu penelitian siklus I sesuai dengan jadwal pelajaran penjas kelas VII.4 SMPN 3 Selat. Setelah berdiskusi dengan kolaborator terhadap kelemahan dan kekurangan siklus I, dilanjutkan pebaikan pada siklus II. Subjek penelitian ini adalah siswa Kelas VII.4 SMPN 3 Selat Negeri 3 Selat yang berjumlah 30 siswa terdiri dari 13 siswa laki-laki dan 17 siswa perempuan.

Metode penelitian yang digunakan adalah Penelitian Tindakan Kelas (PTK). Menurut Arikunto (2014:75) menyatakan bahwa "penelitian tindakan yang diawali dengan perencanaan (planning), penerapan tindakan (action), mengobservasi dan mengevaluasi tindakan (observation and evaluation), dan melakukan refleksi (reflecting), dan seterusnya sampai perbaikan atau peningkatan yang diharapkan tercapai (criteria keberhasilan). Adapun tahapan siklus pada Penelitian Tindakan Kelas ini dapat diterangkan melalui gambar sebagai berikut:

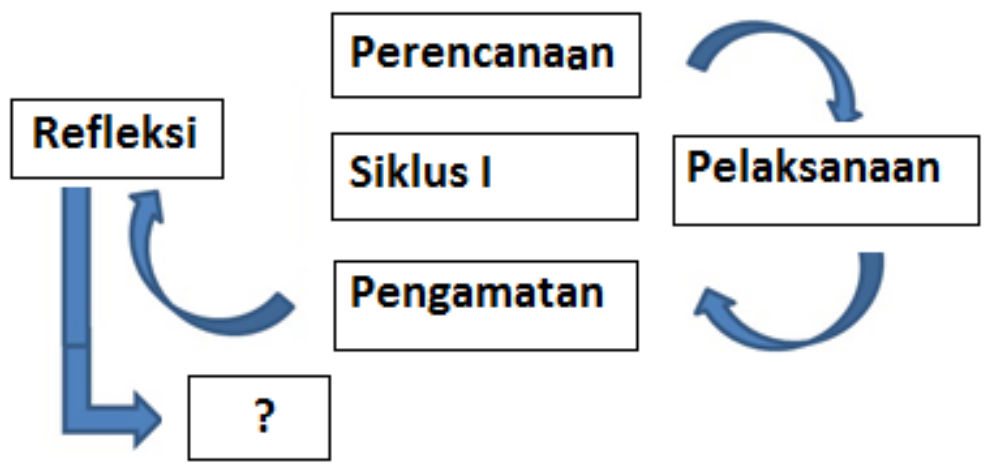

Gambar 1. Siklus penelitian Tindakan Kelas (Arikunto, 2016:16) 
Langkah-langkah penelitian secara prosedurnya dilaksanakan secara partisipatif atau kolaboratif antara (guru dengan tim lainya) bekerjasama, mulai dari tahap orientasi hingga penyusunan rencana tindakan dalam siklus pertama, diskusi yang bersifat analitik, kemudian dilanjutkan dengan refleksi-evaluatif atas kegiatan yang dilakukan pada siklus pertama, untuk kemudian mempersiapkan rencana modifikasi, koreksi, atau pembetulan, dan penyempurnaan pada siklus berikutnya.

Adapun teknik pengumpulan data penelitian ini di antaranya melalui tes praktek, observasi lapangan, dan dokumentasi. Untuk mengumpulkan data, langkah pertama yang dilakukan yaitu menyusun rumusan pengertian secara singkat yang ditemukan dalam pembelajaran setelah itu penyusunan sajian data yang ditulis dan agar lebih jelas dapat dilengkapi dengan gambar, tabel, photo.

Melalui pembelajaran teknik smash dalam permainan tenis meja dengan penggunaan modifikasi alat bantu pembelajaran diharapkan penguasaan teknik dasar permainan tenis meja siswa meningkat menjadi lebih baik dibandingkan sebelumnya. Kemampuan yang diharapkan adalah siswa dapat menguasai cara bermain tenis meja dengan benar dan baik. Dalam penelitian ini ditentukan indikator keberhasilan yaitu apabila pada siklus pertama mencapai 50\% dan pada siklus ke dua mencapai $80 \%$ dari jumlah siswa (21 siswa) dapat memperoleh nilai penguasaan teknik bermain tenis meja sama atau lebih dari Kriteria Ketuntasan Minimal (KKM) yaitu nilai 70.

PTK ini bertujuan untuk mengukur sejauh mana aktivitas guru dan siswa dalam mengusai teknik dasar tenis meja dengan pembelajaran yang inovatif, dan mengukur tingkat kepuasan siswa dalam mengikuti proses belajar-mengajar tenis meja dengan pembelajaran inovatif. Untuk melihat sejauh mana aktivitas guru dan siswa dalam proses belajar-mengajar dan tingkat kepuasan belajar siswa dari proses pembelajaran dapat dilihat dari pencapaian hasil pembelajaran yang sudah ditentukan pada tabel di bawah ini.

Teknik analisis data. Data yang dikumpulkan pada setiap kegiatan observasi dari pelaksanakan siklus PTK dianalisis secara deskriptif dengan menggunakan teknik persentase untuk melihat kecenderungan yang terjadi dalam kegiatan pembelajaran. Sumber data. Data yang dikumpulkan dalam penelitian ini meliputi informasi tentang keadaan siswa dilihat dari aspek kuantitatif dan kualitatif. Aspek kuantitatif yakni hasil pengukuran kemampuan penguasaaan bermain tenis meja. Sedangkan aspek kualitatif didasarkan atas hasil pengamatan dan catatan pembelajaran selama penelitian berlangsung.

Instrumen yang digunakan dalam penelitian ini adalah praktek melakukan gerakan teknik dasar bermain tenis meja, yaitu tes untuk mengukur kemampuan bermain tenis meja. Instrumen tes yang digunakan dalam penelitian ini adalah tes bermain tenis meja yang bertujuan untuk mengukur keterampilan siswa dalam menguasai teknik dasar permainan tenis meja.

\section{HASIL DAN PEMBAHASAN}

\subsection{Deskripsi Kondisi Awal (Pra Siklus)}

Sebelum melaksanakan poses penelitian tindakan kelas, terlebih dahulu peneliti melakukan kegiatan survei awal untuk mengetahui keadaan nyata yang ada di lapangan. Hasil kegiatan survey awal tersebut adalah a) Siswa Kelas VII.4 SMPN 3 Selat Negeri 3 Selat, yang mengikuti materi pelajaran penjas khususnya permainan tenis meja adalah 30 siswa, yang terdiri atas 13 siswa laki-laki dan 17 siswa perempuan. Dilihat dari proses pembelajaran tenis meja khususnya cara bermaian tenis meja, dapat dikatakan proses pembelajaran dalam kategori kurang berhasil. b) Siswa kurang memiliki perhatian dan motivasi dalam pembelajaran bermain tenis meja, sebab guru kurang kreatif dalam mengajar permainan tenis meja. c) Dari hasil pengamatan yang dilakukan diperoleh informasi bahwa siswa cenderung sulit diatur saat materi bermain tenis meja berlangsung. 
Saat mengikuti materi, siswa menunjukkan sikap seenaknya sendiri, tidak memperhatikan penjelasan guru, tidak memperhatikan pelajaran dengan sepenuhnya, ada yang berbicara dengan teman, bahkan ada yang bermain sendiri dengan temannya. d) Kesulitan menemukan contoh model pembelajaran bermain tenis meja yang baik dan benar. Seringkali contoh yang disampaikan melalui peragaan langsung, kurang dapat dicermati oleh siswa secara baik, sebab siswa kurang dapat melihat kondisi gerakan teknik bermain tenis meja yang diperagakan oleh guru, baik karena kurangnya antusiasme siswa atau contoh gerakan kurang dapat dipahami oleh siswa. e) Kurang bisa dapat menarik perhatian siswa dalam pembelajaran. Kurang kreatif untuk membuat cara agar siswa tertarik dan senang mengikuti materi bermain tenis meja. f) Sedikit kesulitan menemukan pendekatan pembelajaran yang baik kepada siswa. pembelajaran yang monoton atau konvensional mengakibatkan motivasi belajar siswa menurun, sehingga akan berdampak pada rendahnya kemampuan siswa dalam bermain tenis meja.

Sebelum melakukan pelaksanaan tindakan maka peneliti dan kolaborator melakukan pengambilan data awal penelitian. Ini dimaksudkan untuk mengetahui kondisi awal keadaan kelas pada materi permainan tenis meja. Adapun diskripsi data yang diambil adalah hasil belajar permainan tenis meja. Kondisi awal hasil belajar bermain tenis meja sebelum diberikan tindakan model pembelajaran melalui penerapan modifikasi alat pembelajaran berdasarkan tabel nilai pada Bab I, disajikan dalam bentuk tabel 1 .

Tabel 1. Diskripsi Data Awal Hasil Belajar Bermain Tenis Meja

\begin{tabular}{|c|c|c|c|c|}
\hline Rentang Nilai & Keterangan & Kreteria & Jumlah anak & $\%$ \\
\hline$\geq 90$ & Memuaskan & Tuntas & 1 & $3, \mathbf{3 3}$ \\
\hline $80-89$ & Baik & Tuntas & 2 & 6,67 \\
\hline $70-79$ & Cukup & Tuntas & 5 & 16,67 \\
\hline $61-69$ & Kurang & Tidak Tuntas & 7 & 23,33 \\
\hline$\leq 60$ & Gagal & Tidak Tuntas & 15 & 50 \\
\hline \multicolumn{3}{|c|}{ Jumlah } & 30 & 100 \\
\hline
\end{tabular}

Berdasarkan hasil diskripsi rekapitulasi data awal sebelum diberikan tindakan maka dapat dijelaskan bahwa mayoritas siswa belum menunjukan hasil belajar yang baik, dengan prosentase ketuntasan belajar memuaskan $3,33 \%$, baik $6,67 \%$, cukup $16,67 \%$ (tuntas = $26,67 \%$ ) siswa.

Melalui diskripsi data awal yang telah diperoleh tesebut masing-masing aspek menunjukkan kriteria keberhasilan pembelajaran yang kurang. Maka disusun sebuah tindakan untuk meningkatkan kualitas pembelajaran materi bermain tenis meja pada siswa Kelas VII.4 SMPN 3 Selat Negeri 3 Selat, melalui penerapan modifikasi alat pembelajaran. Pelaksanaan tindakan akan dilakukan sebanyak 2 siklus, yang masing masing siklus terdiri atas 4 tahapan, yakni: (1) Perencanaan, (2) Pelaksanaan Tindakan, (3) Observasi dan interprestasi, (4) Analisis dan Refleksi.

\subsection{Siklus I}

Perencanaan tindakan pada siklus I pada tanggal 6 Agustus 2019, sebagai berikut: 1) Peneliti melakukan analisis kurikulum untuk mengetahui kompetensi dasar yang akan disampaikan kepada siswa dalam pembelajaran Pendidikan Jasmani Olahraga dan Kesehatan. 2) Membuat rencana pembelajaran dengan mengacu pada tindakan (treatment) yang diterapkan dalam PTK, yaitu penerapan modifikasi alat pembelajaran untuk permainan tenis meja. 3) Menyiapkan media yang diperlukan untuk membantu pengajaran. 4) Menyusun lembar pengamatan pembelajaran. 
Tahap pelaksanaan dilakukan dengan melaksanakan scenario pembelajaran yang telah direncanakan, sebagai berikut: 1) Pemanasan; menjelaskan kegiatan belajar mengajar secara umum dan melakukan pemanasan. Pemanasan dikemas dalam sebuah permainan sederhana yaitu Hitam dan Hijau. Caranya siswa dibagi menjadi dua kelompok tim hitam dan tim hijau, di buat satu bans setiap tim dan di hadapkan saling membelakangi, guru sebagai pengatur permainan, bila guru bilang hitam, tim hijau mengejar tim hitam dengan melompat dan tim hitam melompat ke depan lurus agar tidak tertangkap, bila tim hitam sampai batas belum tertangkap maka tim hijau menggendong tim hitam dari batas menuju ke posisi awal tetapi apabila tim hitam tertangkap maka tim hitam yang menggendong, apabila guru bilang hijau maka tim hitam yang mengejar.

Selanjutnya 2) Inti Pelajaran; memberi panjelasan materi yang akan diberikan, siswa melakukan gerak dan teknik dasar gerakan servis pada permainan tenis meja, siswa di bagi menjadi 2 regu. Siswa melakukan gerakan servis ke arah siswa regu yang lain dan kembali ke barisan dan menempati tempat yang paling belakang, siswa melakukan gerakan menerima servis supaya bola kembali ke area permainan lawan, siswa melakukan latihan bermain tenis meja dengan cara memantulkan bola ke arah dinding, dan siswa mencoba melakukan rangkaian gerakan permainan tenis meja dengan menggunakan media dinding sebagai lawan. Setelah melakukan teknik-teknik bermain tenis meja melalui penerapan modifikasi alat pembelajaran, kemudian siswa melakukan rangkaian gerakan secara keseluruhan dengan lapangan yang sesungguhnya dan sebagai lawannya adalah teman sendiri. Siswa melakukan sesuai urutan absen.

Pada kegiatan penutup dilakukan; penenangan/pendinginan, siswa duduk bersap, rapat, dan saling memijat, laki-laki dan perempuan di pisah, evaluasi mengenai pembelajaran yang telah dilakukan, dan berdoa kemudian dibubarkan.

Pada dasarnya pembelajaran melalui pendekatan modifikasi alat pembelajaran cukup memberikan gairah dan semangat baru pada pembelajaran smash dalam permainan Tenis Meja, hal ini dapat diamati dari sikap siswa yang tak kenal menyerah pada saat melakukan tes dan selalu ingin mengulangi permainan ketika hasilnya belum memenuhi target yang diharapkan. Masih ada kesempatan pada siklus II dengan harapan hasilnya akan lebih baik.

Tabel 2. Diskripsi Data Akhir Siklus I Hasil Belajar bermain tenis meja

\begin{tabular}{|c|c|c|c|c|}
\hline Rentang Nilai & Keterangan & Kreteria & Jumlah anak & $\%$ \\
\hline$\geq 90$ & Memuaskan & Tuntas & 1 & 3,33 \\
\hline $80-89$ & Baik & Tuntas & 2 & 6,67 \\
\hline $70-79$ & Cukup & Tuntas & 11 & 36,67 \\
\hline $61-69$ & Kurang & Tidak Tuntas & 11 & 36,67 \\
\hline$\leq 60$ & Gagal & Tidak Tuntas & 5 & 16,67 \\
\hline \multicolumn{3}{|c|}{ Jumlah } & 30 & 100 \\
\hline
\end{tabular}

Dari tabel 2 menujukkan bahwa hasil belajar siswa meningkat sesuai target capaian yang dicantumkan pada proposal. Meskipun demikian, masih perlu peningkatan pada metode yang diterapkan. Adapun keberhasilan dan kegagalan yang terjadi pada pertemuan kali ini adalah sebagai berikut:

\section{Keberhasilan guru/siswa:}

Berdasarkan pada kondisi awal, siswa menunjukkan hasil belajar dengan prosentase memuaskan 3,33\%, baik 6,67\%, cukup 36,67, siswa yang tuntas 46,67\% dan kategori kurang $36,67 \%$, gagal $16,67 \%$, siswa yang belum tuntas $50,00 \%$. 


\section{Kendala yang dihadapi guru/siswa:}

Kendala demi kendala bisa diatasi sedikit demi sedikit meskipun masih perlu peningkatan dan pengembangan. Kendala tersebut diantaranya adalah masih banyaknya siswa yang bermain sendiri dan tidak aktif dikarenakan terlalu panjangnya antrian serta kurangnya alat berupa bet. Demi tercapainya hasil yang maksimal pendekatan internal pada setiap individu siswa masih sangat berperan terhadap semangat siswa. Observasi aktivitas guru dalam proses penelitian siklus I adalah sebagai berikut; dalam membuka pelajaran sudah baik, keterampilan menjelaskan materi pada siswa baik, pengelolaan kelas cukup baik walaupun masih ada sedikit kegaduhan, melaksanakan pembelajaran sesuai dengan RPP, interaksi dengan siswa dan member motivasi terhadap siswa, mengarahkan dan membimbing siswa agar lebih baik, menutup pelajaran

\section{Rencana Perbaikan}

Berdasarkan hasil analisis dalam pembelajaran siklus satu, maka perlu ada perbaikanperbaikan pada siklus berikutnya, antara lain adalah: a) mempersiapkan siswa secara fisik dengan mengbimbau siswa supaya tidak melakukan gerakan yang menguras tenaga sebelum latihan, misalnya bermain kejar- kejaran dengan temannya dan bercanda sendiri, b) melakukan pendekatan internal lebih intensif pada siswa yang dirasa masih kurang berhasil, c) memberikan motivasi lebih kepada siswa supaya menjadi tambah semangat dalam mengikuti kegiatan belajar mengajar yang dilakukan dalam pembelajaran tenis meja, dan d) menambahkan bet agar antrian tidak terlalu panjang sehingga siswa tidak banyak yang menganggur

\subsection{Siklus II}

Berdasarkan dari hasil analisis dan refleksi pada siklus pertama, maka perencanaan pada siklus II tanggal 20 Agustus 2019 adalah sebagai berikut: 1) membuat RPP dengan mengacu pada pertemuan sebelumnya. Pembelajaran dengan modifikasi alat pembelajaran yang pada pertemuan sebelumnya kurang berhasil dibuat lebih menarik lagi, 2) menyiapkan media yang diperlukan untuk membantu pengajaran, dan 3) menyusun lembar pengamatan pembelajaran.

Tahap pelaksanaan dilakukan dengan melaksanakn skenario pembelajaran yang telah direncanakan, sebagai berikut: 1) pemanasan; menjelaskan kegiatan belajar mengajar secara umum, melakukan pemanasan. Pemanasan dikemas dalam sebuah permainan sederhana yaitu permainan bola ranting. Siswa dibariskan berbanjar dua regu, barisan depan membawa masing-masing satu bola, kemudian bola dioperkan kebelakang. Barisan paling belakang kemudian berlari ikedepan dan mengoperkan kembali kebelakang, begitu seterusnya. 2) inti Pelajaran; memberi panjelasan materi yang akan diberikan. Siswa melakukan gerak dan teknik smash dalam permainan tenis meja. Siswa di bagi menjadi 2 regu, Siswa memukul bola yang dilemparkan oleh temannya dan dari arah meja berlawanan kemudian siswa melakukan gerakan smash dan kembali kebarisan paling belakang. Siswa di bagi dua sab dengan jarak masing-masing 2 rentang lengan. Siswa melakukan latihan teknik smash dalam permainan tenis meja dengan memukul bola yang dilemparkan dari arah meja berlawanan. Siswa mencoba melakukan rangkaian gerakan teknik smash dengan media bola banyak masing-masing mendapat giliran memukul 10 bola bergantian. Setelah siswa melakukan rangkaian gerakan smash dengan bola banyak, Siswa melakukan teknik-teknik smash dengan modifikasi alat pembelajaran, kemudian siswa melakukan rangkaian gerakan secara keseluruhan. Siswa melakukan sesuai unit absen dan diambil hasil belajar yang sudah ditunjukkan oleh siswa sebagai bahan evaluasi pada Siklus II.

Pada kegiatan penutup; melaksanakan penenangan/pendinginan. Pendinginan dilakukan berupa pelemasan dengan cara saling memijit kaki teman. Setelah pendinginan, 
dilakukan evaluasi mengenai pembelajaran yang telah dilakukan. Evaluasi dilakukan dengan memberikan waktu pada anak untuk bertanya gerakan mana yang dirasa cukup sulit dan peneliti memberikan respon dengan menerangkan gerakan-gerakan yang seharusnya dilakukan dengan benar. Berdoa dan siswa dibubarkan.

Dari hasil observasi disimpulkan bahwa siswa semakin antusias melakukan pembelajaran, tampak tidak ada kejenuhan dari siswa. Siswa tidak malas belajar dan selalu ingin menambah tempo belajar. Saat pemanasan siswa terlihat senang dan gembira dengan pemanasan yang dikemas dengan cara permainan. Siswa lebih banyak bergerak dan melakukan dengan rasa antusias. Pada saat pembelajaran siswa tampak senang dengan penyajian materi. Melalui modifikasi alat pembelajaran siswa sudah mulai bisa menikmati pembelajaran dan karena model kompetisi yang digunakan, siswa terlihat saling ingin mengalahkan teman yang lainnya. Siswa juga senang dengan modifikasi alat pembelajaran yang diberikan. Hal ini terlihat dari sikap siswa yang cenderung selalu ingin mencoba lagi. Pada pembelajaran smash dalam permainan tenis meja, dilakukan secara keseluruhan. Dari belajar teknik dasar sampai bermain tenis meja siswa terlihat senang dengan modifikasi alat pembelajaran yang diberikan dan cukup membuat siswa merasa tertantang untuk bermain tenis meja.

Pada pembelajaran dengan modifikasi alat pembelajaran cukup memberikan gairah dan nuansa baru pada pembelajaran bermain tenis meja, hal ini dapat dilihat dari hasil tes pada siklus II yang memuaskan.

Tabel 3: Diskripsi Data Akhir Siklus II Hasil Belajar bermain Tenis Meja

\begin{tabular}{|c|c|c|c|c|}
\hline Rentang Nilai & Keterangan & Kreteria & Jumlah anak & $\%$ \\
\hline$\geq 90$ & Memuaskan & Tuntas & 1 & 3,33 \\
\hline $80-89$ & Baik & Tuntas & 5 & 16,67 \\
\hline $70-79$ & Cukup & Tuntas & 20 & 66,67 \\
\hline $61-69$ & Kurang & Tidak Tuntas & 3 & 10,00 \\
\hline$\leq 60$ & Gagal & Tidak Tuntas & 1 & 3,33 \\
\hline \multicolumn{3}{|c|}{ Jumlah } & 30 & 100 \\
\hline
\end{tabular}

Dari hasil tes pada siklus II menunjukkan bahwa hasil belajar bermain tenis meja yang dilakukan oleh siswa meningkat dari $26.67 \%$ pada kondisi awal menjadi 46,67\% pada akhir siklus I dan meningkat menjadi $86,67 \%$ pada akhir siklus II. Perbandingan hasil belajar pada akhir siklus I dan akhir siklus II disajikan dalam bentuk diagram 1.

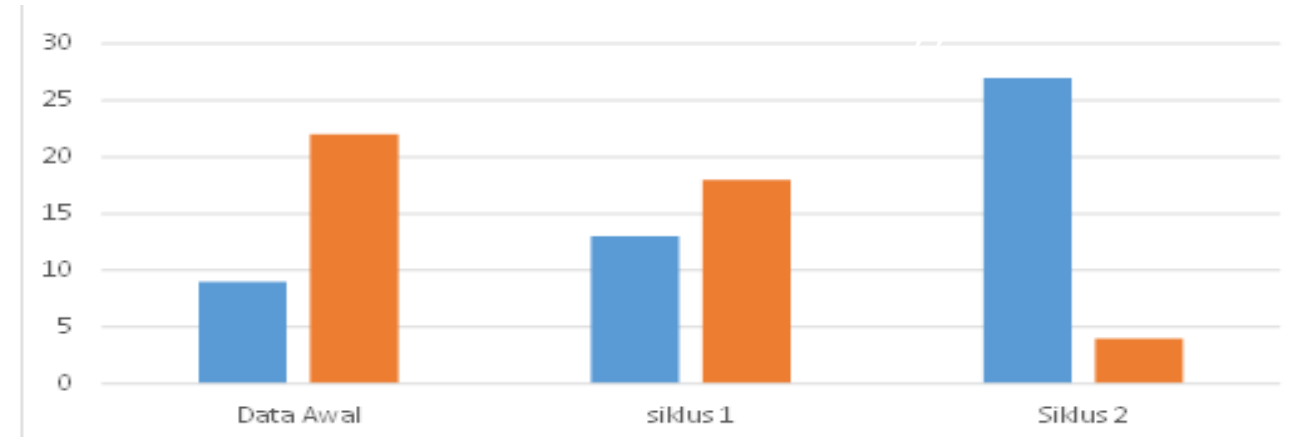

Diagram 1. Perbandingan Jumlah Siswa Data Awal, Siklus I dan Siklus II Hasil Belajar bermain Tenis Meja 
Dengan hasil yang mengacu pada diagram tersebut maka dapat disimpulkan bahwa dengan penerapan modifikasi alat pembelajaran memberikan banyak manfaat dan pencerahan dalam metode pembelajaran teknik dasar dan bermain tenis meja lebih menantang siswa untuk melakukan latihan bermain tenis meja pada kegiatan belajar mengajar yang dilakukan.

\subsection{Pembahasan}

Hasil Penelitian Tindakan Kelas ini dari kondisi awal sampai ke siklus II mengalami peningkatan yang signifikan. Untuk melihat perbandingan kondisi tersebut dapat dirincikan kedalam diagram 2.

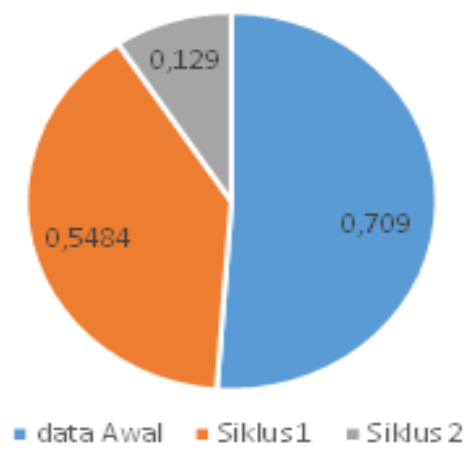

Tidak Tuntas

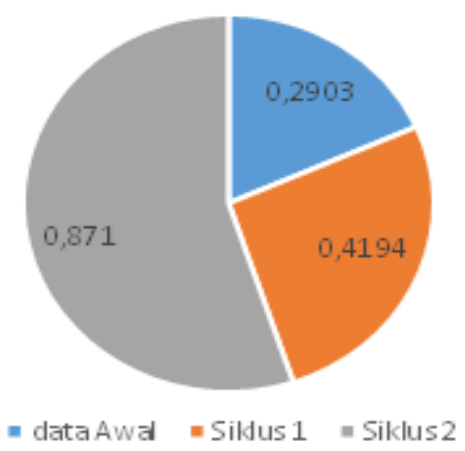

Tuntas

\section{Diagram 1. Perbandingan Persetase Data Awal, Siklus I dan Siklus II Ketuntasan Hasil Belajar bermain Tenis Meja}

Berdasarkan hasil penelitian, kondisi awal atau pra siklus ketuntasan hasil belajar yang memiliki ketuntasan 29,03\%. Sedangkan yang tidak tuntas adalah 70,97\%. Hasil belajar pra siklus materi bermain tenis meja yang menjadi rumusan masalah penelitian, melalui media dinding peneliti mengharapkan dapat meningkatkan hasil belajar bermain tenis meja.

Pada siklus I yang memiliki kategori tuntas 41,94\% sebanyak 13 siswa, kategori tidak tuntas 54,84\% sebanyak 18 siswa. Setelah adanya penerapan media memantul bola ke dinding terlihat peningkatan yang cukup baik pada siswa. Dalam pelaksanaan siklus I tidak lepas dari ketidak tuntasan hasil belajar, yang mana ketidak tuntasan tersebut menjadi rencana perbaikan pada pelaksanaan siklus II.

Rencana perbaikan yang didapat dari siklus I yang dijadikan persiapan tindakan dan menghasilkan ketuntasan yang memuaskan. Dari hasil tes pada siklus II menunjukkan bahwa hasil belajar bermain tenis meja yang dilakukan oleh siswa meningkat dari 29,03\% pada kondisi awal menjadi $41,94 \%$ pada akhir siklus I dan meningkat menjadi $87,10 \%$ pada akhir siklus II.

\section{SIMPULAN}

Penelitian Tindakan Kelas pada kelas VII.4 SMPN 3 Selat dilaksanakan dalam dua siklus. Setiap siklus terdiri atas empat tahapan, yaitu: 1) perencanaan, 2) pelaksanaan tindakan, 3) observasi dan interpretasi, dan 4) analisis dan refleksi. Berdasarkan analisis data yang telah dilakukan dan pembahasan yang telah diungkapkan pada Bab IV, diperoleh simpulan bahwa pembelajaran melalui penerapan modifikasi alat pembelajaran dapat meningkatkan hasil belajar bermain Tenis Meja. Dari hasil analisis yang diperoleh peningkatan yang signifikan dari siklus I dan s iklus II. Hasil belajar Bermain Tenis Meja pada siklus I dalam 
kategori tuntas adalah 45,16\% jumlah siswa yang tuntas adalah 14 siswa. Pada siklus II terjadi peningkatan prosentase hasil belajar siswa dalam kategori tuntas sebesar $87,10 \%$, sedangkan siswa yang tuntas 27 siswa.

\section{DAFTAR PUSTAKA}

Arikunto, Suharsimi dkk. 2014. Penelitian Tindakan Kelas. Jakarta: Bumi Aksara.

Damiri, Achmad. 1992. Olahraga Pilihan Tenis Meja, Jakarta. Departemen Pendidikan dan Kebudayaan.

Asri Budiningsih, 2005. Belajar dan Pembelajaran. Jakarta. Rineka Cipta.

Fimeir Liady, 2007. Design Penelitian. Kapuas. STAI Kuala Kapuas.

Hamzah dan Nurdin, Mohamad, dkk. 2016. Belajar dengan Pendekatan PAIKEM, Jakarta : Bumi Aksara

Mardalis, 1993. Prosedur Penelitian Suatu Pendekatan Proposal. Jakarta. Bumi Aksara.

Muhajir. 2016. Pendidikan Jasmani Olahraga dan Kesehatan, Jakarta: Kementrian Pendidikan dan Kebudayaan Republik Indonesia

Piter Simson. 1986. Teknik Bermain Tenis Meja, Bandung. Pioner.

Pupuh Fathurrohman dan Sobry Sutikno, 2007. Strategi Belajar Mengajar. Refika Aditama. Jakarta. 